\title{
SCIENCE LEARNING TRAINING USING INFORMATION TECHNOLOGY IN THE COVID-19 PANDEMIC
}

\author{
${ }^{1)}$ Muhammad Taufiq, ${ }^{2)}$ Noer Laelly Baroroh TAG, ${ }^{3)}$ Estin Nofiyanti, \\ ${ }^{4)}$ Nandhini Hudha Anggarasari \\ 1) Pendidikan Teknologi Informasi ${ }^{4)}$ Pendidikan Guru Pendidikan Anak Usia Dini, FKIP \\ 2) Teknik Elektro, ${ }^{3)}$ Teknik Lingkungan, F. Teknk, \\ Universitas Muhammadiyah Tasikmalaya \\ mtaufiq@umtas.ac.id,Nlaelly@yahoo.com,estin.nofi@umtas.ac.id,nandhini.hagrs@umtas.ac.id,
} 081391642945

\begin{abstract}
The Covid-19 pandemic has a direct impact on the environment of society, both regarding aspects of knowledge and aspects of problem solving which are all trial and error or speculative on various things, as a result in the world of education it is also inseparable from various problems, so that not a few end up leading to conflicts or debate. This community service program (PKM) is aimed at SMA Muhammadiyah Pangandaran teachers with the aim of being able to help solve problems, especially those related to the Teaching and Learning Process in the form of networks (online) in the field of science learning. For this reason, it is necessary to have a technology device that can help teaching and learning activities, especially internet-based information technology applications, with the hope that the online teaching and learning process can take place as it should. and motivate teachers to teach. The results of this PKM activity are in the form of increased motivation or enthusiasm for teaching and additional insight into the use of Information Technology (IT) in carrying out the On Line-based Teaching and Learning Process. In conclusion, the PKM which was appointed under the title Science Learning Training Using Information Technology in the Covid-19 Pandemic Period provided an adequate contribution to 32 SMA Muhammadiyah Pangandaran teachers as training participants.
\end{abstract}

Keywords: Covid-19 Pandemic, Training, Information Technology, Teaching and Learning Process

\section{INTRODUCTION}

Community Service is one of a series of activities for implementing Higher Education Catur Dharma at the Muhammadiyah University of Tasikmalaya, for that lecturers are required to be able to realize the chess dharma as a consequence and professional responsibility carried out in the hope of being able to support the realization of the vision and mission of the Higher Education. The implementation of community service is organized by lecturers together with a number of students from the Faculty of Teacher Training and Education (FKIP) in the Information Technology Education and Early Childhood Education study program, as well as collaborating with the Faculty of Engineering in the Electrical Engineering and Environmental Engineering study program.

The mandate of the opening of the 1945 Constitution, namely educating the nation's life as stated in Article 31 paragraph (1) of the 1945 Constitution that "Every citizen has 
the right to education.", the role of the government is to realize the importance of education, so that the allocation of education funds is explicitly stated in the 1945 Constitution. Article 31 paragraph (4) of the 1945 Constitution which reads: "The state prioritizes the education budget at least twenty percent of the state revenue and expenditure budget as well as from the regional revenue and expenditure budget to meet the needs of national education administration.

In this case, the government is not alone, elements of society in the form of community organizations (ormas), including Muhammadiyah are asked to be involved in dealing with educational problems during the Covid-19 pandemic, then through the Muhammadiyah Covid-19 Command Center (MCCC) Pangandaran and the Primary and Secondary Education Council. (Dikdasmen) Regional Leaders of Muhammadiyah (PDM) Pangandaran, proposed the need for a direct action related to the world of education, namely Teaching and Learning Activities, in the form of training socialization on online learning in the era of the Covid-19 pandemic.

Online learning (Mustakim, 2020) is often referred to as distance learning, which is a virtual learning process that is accessed via the internet (network) and computer networks or known as online learning (in networks) in the form of learning methods that use internet-based interactive models and Learning Management System (LMS), such as using Zoom, Google Classroom, and others. Along with the new normal era, offline learning (outside the network) emerged, namely learning with a system without a computer network anymore, the form can be in the form of face-to-face which is limited to certain conditions, namely following the limits of applicable health protocols, it can be in the form of watching television or reading books/documents.

Based on the results of the dialogue with the Community Service partner, SMA Muhammdiyah Pangandaran, it was found that there were basic problems in the motivation and potential of existing teachers, particularly related to the Teaching and Learning Process during the Covid-19 pandemic in the field of science learning, in the form of a) Decreased teacher enthusiasm in teaching (demotivation). b) Lack of knowledge of teachers on the use of technology in internet-based teaching and learning activities

The theory of motivational needs according to David Mc, Cleland (Aziti, 2019) focuses on 3 (three) needs, namely the need for achievement ( $n$-Ach), the need for power (need of power / n-Pow) and the need for affiliated (need of affiliation / n-Aff). These three needs are very important in relation to the motivation of a person (teacher) to become better in an organizational environment (school), thus it is necessary to consider making improvements and also changing mindsets (way of thinking), through direct coaching. The form of coaching is in the form of self-potential development training, namely Information Technology-based science learning training, with the hope of being able to change work patterns in Teaching and Learning Activities that are better than before. For this reason, this training contains 3 (three) programs, namely 1) pandemic orientation in the world of education, 2) positive and productive teaching motivation, 3) Information technology-based learning techniques. 


\section{MATERIALS AND METHODS}

This Community Service Activity is an activity in the form of training or learning counseling in the field of science to a number of 32 permanent teachers at SMA Muhammadiyah Pangandaran which was held in October 2020, while the data collection technique (sampling) used in this Community Service is simple. random sampling with the consideration that the existing population members are relatively homogeneous and the amount of data is not large enough, so that data collection is carried out randomly from the existing population, while data analysis is carried out using qualitative and quantitative analysis, descriptive statistical data presented in the form of a questionnaire. filled in with 4 (four) parameters, namely 1) Less, 2) Enough, 3) Good, and 4) Very good, then the processed data results are presented in diagrams and percentage graphs, while for qualitative analysis, questionnaires are used in the form of testimonials and suggestions for activities. training

There are 7 descriptive aspects, namely the suitability of the implementation of the activity with the purpose of the activity, the suitability of the activity with the needs of the participants. Adding insight, the suitability of the resource persons' competencies with the needs of the activity, the suitability of the schedule with the implementation of the activity, the quality of the overall Science Learning Training system, the quality of the training materials provided in the training. Overall Science Learning, Committee service quality. The device used in this case is a computer technology device with material in the form of a question questionnaire (quiz) using the Google Form application facility, while for processing it uses the Ms Excel application.

\section{RESULTS}

The results obtained in the implementation of Community Service activities at SMA Muhammadiyah Pangandaran are the implementation of activities for partners in the form of science learning training for all 32 permanent teachers, the goal is to provide education and motivation in carrying out teaching activities during the covid-19 pandemic, as for the form of training carried out in class in the form of lectures, role playing, games, problem cases, simulations and participant practicums using computer equipment with several internet-based teaching applications, besides that there are game tools to build motivation and potential for participants, after that a closing event for PKM activities is held. in Pangandaran with PKM partners.

The material presented during the training was divided into three sessions, namely pandemic orientation in education, positive and productive teaching motivation, and Information Technology-based learning techniques. To measure the success rate of community service activities, observations were made during the activity and interviews with several teachers as training participants, and qualitatively the results were that the participants were satisfied because they got additional knowledge and enthusiasm to continue teaching. It really helps us to develop learning models for students, the training is very helpful, as a distance learning reference. The material presented is very useful, while some of the suggestions given are also positive, including this training is very useful for educators, we will schedule activities like this on a regular basis, training like this is easy to carry out regularly 
The results of the evaluation questionnaire to the participants from 32 teachers there were around 19 teachers as random samples who had filled in the meaning 19/32 or $59.4 \%$, the content of the questionnaire contained 7 evaluation criteria, in the form of 1) Conformity of the implementation of the activity with the purpose of the activity, 2) Conformity Activities with the needs of participants in the Addition of Insights, 3) The suitability of the competence of resource persons with the needs of the activities, 4) The suitability of the schedule with the implementation of the activities, 5) The quality of the overall Science Learning Training system, 6) The quality of the training materials provided in the Science Learning Training as a whole, 7 ) Quality of committee service

The device used for the evaluation process is carried out using a google form with a link:

https://docs.google.com/forms/d/15cMuAEss1p52Rql4VI3m29X7UTUkCXjy6eAddruLY W4/edit?usp=sharing, As for the evaluation results in the form of the overall average success of the training based on the 7 criteria above, it is divided into 4 (four) kinds of parameters, namely 1) Less, 2) Enough, 3) Good, and 4) Very Good, with the percentage of success being $0 \%$, Enough by $5 \%$, Good by $56 \%$, and Very Good by $40 \%$.

\section{DISCUSSION}

Based on the results obtained in the evaluation activities, it can be discussed that the science learning training that has been held at SMA Muhammadiyah Pangadaran as a series of Community Service activities for the lecturers of the Muhammadiyah University of Tasikmalaya, can be declared successful and even close to very good scores, besides getting support as well as the extraordinary enthusiasm of the training participants, this was shown by the participants taking part in the overall training event which was held from the beginning to the end of the event, other things were also shown from the questionnaire filled out notes related to activities (testimonials) and suggestions given.

Obstacles experienced during the implementation of science learning training activities are the equalization of perceptions and understanding between participants which requires separate time, while technical issues are not too significant, because they can still be handled properly, so that this kind of training should have follow-up as a continuous form of training activities. , so that partners can continue to increase their potential continuously in working as teachers at SMA Muhammadiyah Pangandaran

\section{CONCLUSIONS AND SUGGESTIONS}

Conclusions from all community service activities, in the form of direct positive and productive impacts received for training participants, valuable experience for implementing PKM activities as a whole, both regarding friendship, utilization of knowledge and knowledge for the community, aspects of understanding community needs for self-development, The ability of teachers to overcome problems in the field of learning (Teaching and Learning Process) for students of SMA Muhammadiyah Pangandaran during the Covid-19 Pandemic, The ability of SMA Muhammadiyah Pangandaran teachers in utilizing and utilizing Information and Computer Technology in the Teaching and Learning Process, Generating the enthusiasm of teachers to remain enthusiasm in the COVID-19 pandemic, Exploring the potential of Muhammadiyah 
Pangandaran High School teachers by getting to know themselves through an educational game, Building collaboration between the University of Muhammadiyah Tasikmalaya and Muhammadiyah High School Pangandaran and Mu hammadiyah Covid19 Command Center (MCCC) Pangandaran

Suggestions that can be conveyed from the results of training activities in the form of maintaining or establishing friendly relations with partners, in this case are SMA Muhammadiyah Pangandaran and Muhammadiyah Covid-19 Command Center (MCCC) Pangandaran, Intensify information technology-based learning training programs for education civitas in high school Muhammadiyah, both teachers and students, continuous assistance from preparing learning modules to evaluating online learning at SMA Muhammadiyah Pangandaran, the UMTAS campus or through LPPM conducting monitoring and evaluation on location directly, as a follow-up effort in meeting the needs of people who in line with the College dharma chess program.

\section{THANK-YOU NOTE}

I am grateful for the presence of the divine rabbi and thanks to 1) the Chancellor of the University of Muhammadiyah Tasikmalaya. 2) UMTAS Research Institute and Community Partnership Program (LPPM). 3) Lecturers in FKIP and UMTAS Faculty of Engineering. 4) Muhammadiyah Covid-19 Command Center (MCCC) Pagandaran and PDM Pangandaran. 5) UMTAS students who are involved in activities. 6) Teacher of SMA Muhammadiyah Pangandaran

\section{REFERENCES}

Aziti, Tria Meisya. "Pengaruh Motivasi Kekuasaan, Motivasi Afiliasi, Dan Motivasi Berprestasi Terhadap Kinerja Karyawan PT X" Management and Entrepreneurship $\begin{array}{llllll}\text { Journal. } & \text { Vol. } & 2, & \text { No. } & 2 & \text { (2019): }\end{array}$ http://jurnal.unnur.ac.id/index.php/manners/article/viewFile/278/265

Mustakim, "Efektivitas Pembelajaran Daring Menggunakan Media Online Selama Pandemi Covid-19 Pada Mata Pelajaran Matematika", Al asma: Journal of Islamic Education ISSN 2715-2812 (Online) Vol. 2, No. 1, May 2020, http://journal.uinalauddin.ac.id/index.php/alasma/article/view/13646

Oktafia Ika Handarini, Siti Sri Wulandari, "Pembelajaran Daring Sebagai Upaya Study From Home (SFH) Selama Pandemi Covid 19", Jurnal Pendidikan Administrasi Perkantoran (JPAP) Volume 8, Nomor 3, 2020, https://journal.unesa.ac.id/

Aplikasi Pembelajaran Daring Kerjasama Kemendikbud, link:

https://edukasi.kompas.com/read/2020/03/22/123204571/12-aplikasi-pembelajaran-daring-

kerjasama-kemendikbud-gratis?page $=$ all

Mohammad Mulyadi, Penelitian Kuantitatif Dan Kualitatif Serta Pemikiran Dasar Menggabungkannya, Jurnal Studi Komunikasi Dan Media Vol. 15 No. 1 (Januari Juni 2011), https://www.neliti.com/id/publications/134513/penelitian-kuantitatif-dankualitatif-serta-pemikiran-dasar-menggabungkannya

Dwiki Muda Yulanto, Hanapi Hasan, Sapitri Januariyansah, "Panduan Penggunaan Google Classroom Untuk Siswa, Program Kemitraan Masyarakat Universitas Negeri Medan 2020, : https://www.researchgate.net/publication/347512004 


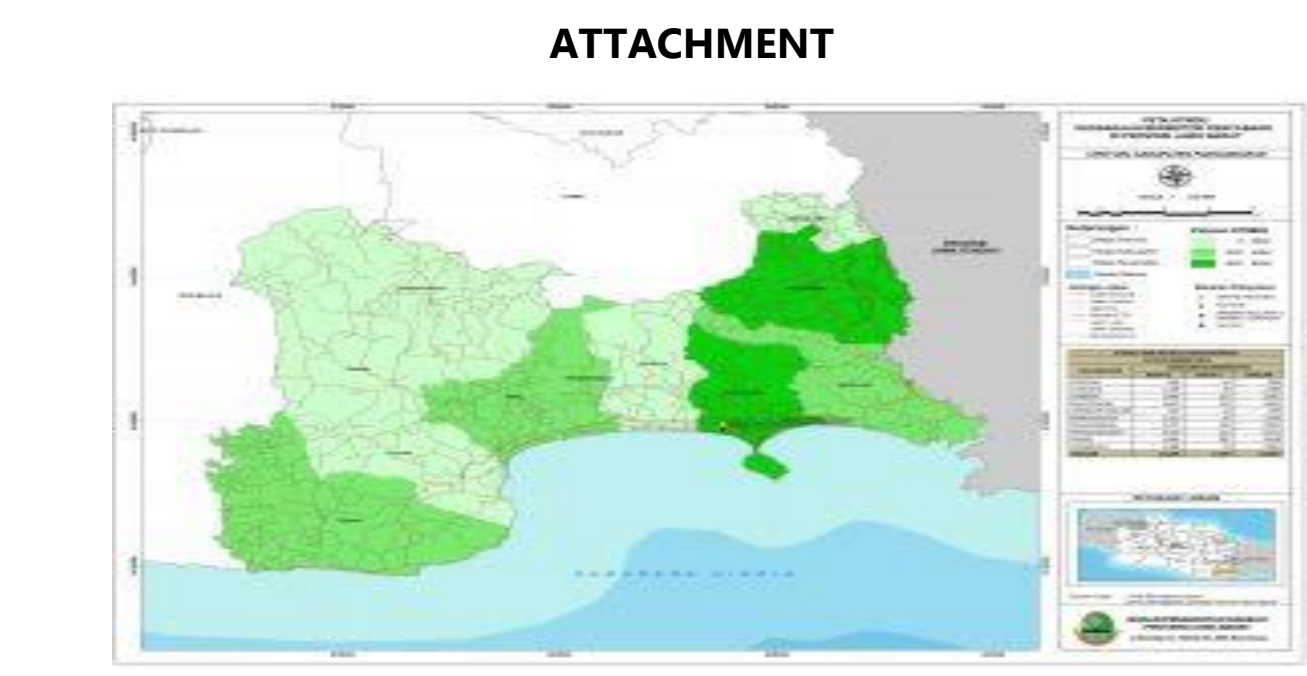

Table 1. Participants' Response Results

\begin{tabular}{|c|c|c|c|c|c|c|c|c|}
\hline $\begin{array}{l}\text { KRITERIA } \\
\text { EVALUASI }\end{array}$ & $\begin{array}{c}1- \\
\text { Kurang }\end{array}$ & $\begin{array}{c}\% \\
\text { Kurang }\end{array}$ & $\begin{array}{c}2- \\
\text { Cukup }\end{array}$ & $\begin{array}{c}\% \\
\text { Cukup }\end{array}$ & $\begin{array}{c}\text { 3- } \\
\text { Bai } \\
\text { k }\end{array}$ & $\begin{array}{c}\% \\
\text { Baik }\end{array}$ & $\begin{array}{l}\text { 4-Baik } \\
\text { Sekali }\end{array}$ & $\begin{array}{l}\% \text { Baik } \\
\text { Sekali }\end{array}$ \\
\hline 1 & 0 & $0 \%$ & 1 & $5 \%$ & 9 & $47 \%$ & 9 & $47 \%$ \\
\hline 2 & 0 & $0 \%$ & 1 & $5 \%$ & 9 & $47 \%$ & 9 & $47 \%$ \\
\hline 3 & 0 & $0 \%$ & 1 & $5 \%$ & 9 & $47 \%$ & 9 & $47 \%$ \\
\hline 4 & 0 & $0 \%$ & 1 & $5 \%$ & 15 & $79 \%$ & 3 & $16 \%$ \\
\hline 5 & 0 & $0 \%$ & 1 & $5 \%$ & 10 & $53 \%$ & 8 & $42 \%$ \\
\hline 6 & 0 & $0 \%$ & 1 & $5 \%$ & 13 & $68 \%$ & 5 & $26 \%$ \\
\hline 7 & 0 & $0 \%$ & 0 & $0 \%$ & 9 & $47 \%$ & 10 & $53 \%$ \\
\hline \multicolumn{2}{|c|}{$\begin{array}{l}\text { Rerata Keberhasilan } \\
\text { Keseluruhan }\end{array}$} & $0 \%$ & & $5 \%$ & & $56 \%$ & & $40 \%$ \\
\hline
\end{tabular}



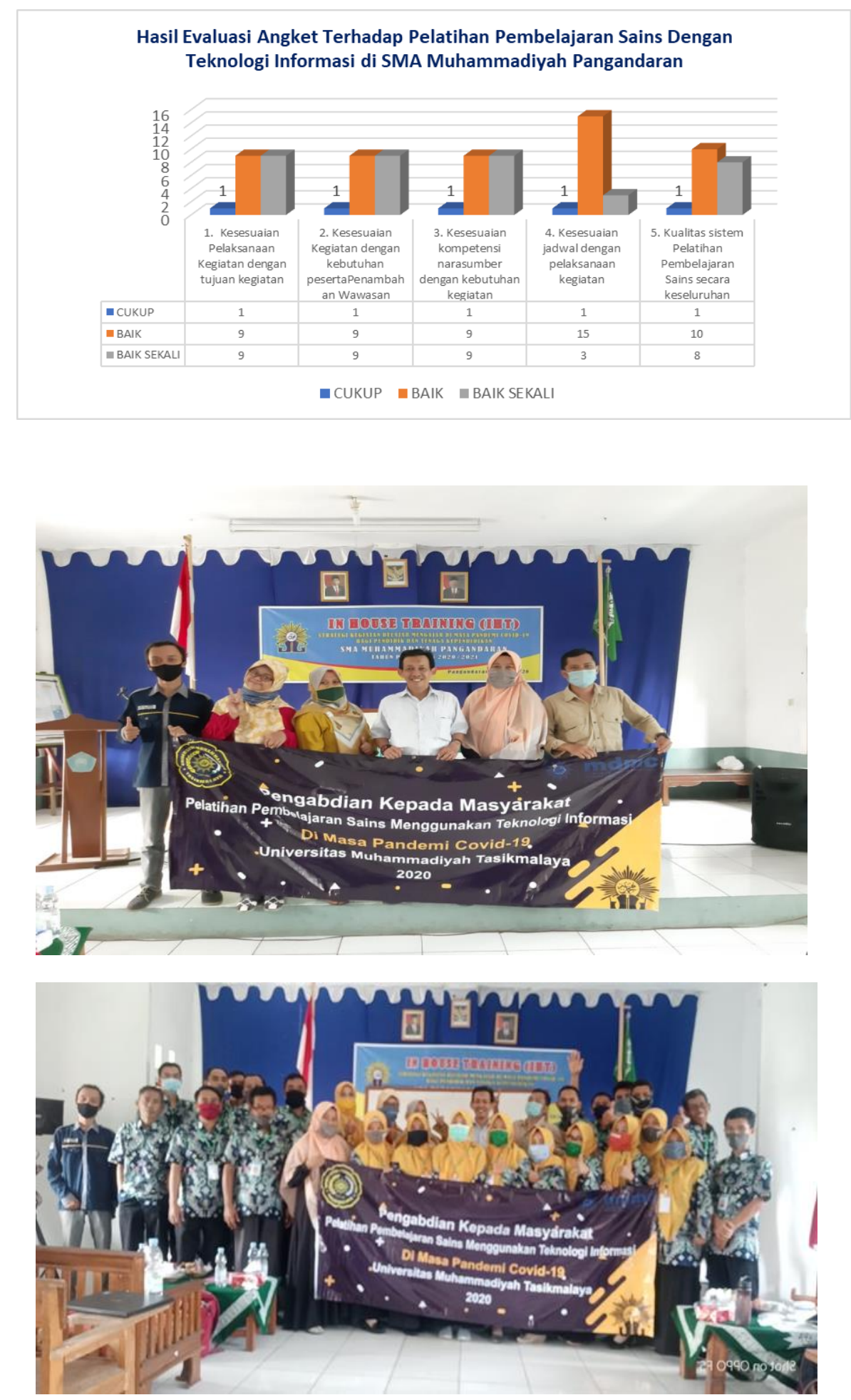


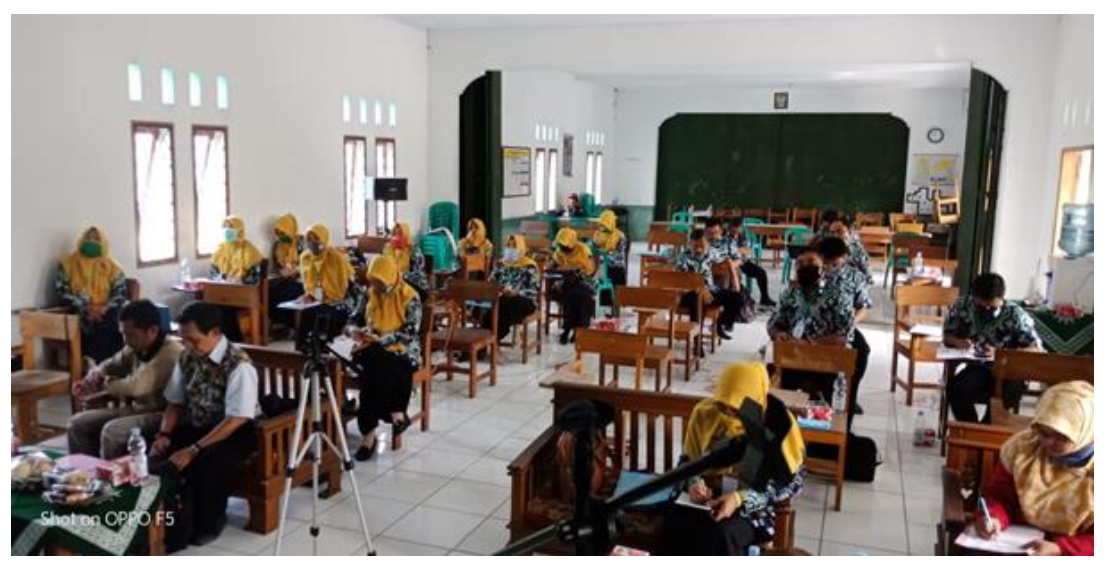

Figure 5. Training Atmosphere in Community Service Activities 
Table 2. List of Participants of the Science Learning Training

\section{ATTENDANCE LIST OF IN HOUSE TRAINING (IHT) PARTICIPANTS MUHAMMADIYAH HIGH SCHOOL OF PANGANDARAN \\ ACADEMIC YEAR 2020-2021}

\begin{tabular}{|c|c|c|c|}
\hline NO. & Name of Teacher and Staff & Position & Sginature \\
\hline 1 & WARTONO, S. Pd & GURU & \\
\hline 2 & H. AAN NURHAKIM, LC & GURU & \\
\hline 3 & Drs. DADANG HADI P. M. Pd & GURU & \\
\hline 4 & RIKRIK HENDRIK, S.Ag. & GURU & \\
\hline 5 & AZIS ARIANA AORI, S.Pd & GURU & \\
\hline 6 & BELLA KUSUMANINGRUM, M. Pd & GURU & \\
\hline 7 & FERRY ELDIYANTO, S. Pd & GURU & \\
\hline 8 & KIKI PRIATNA DEWI, S. Pd. Si & GURU & \\
\hline 9 & NANING NELASARI, S. Pd.I & GURU & \\
\hline 10 & NOVI ASRI, S. Pd & GURU & \\
\hline 11 & PUPU PURNAMA DEWI, S. Pd & GURU & \\
\hline 12 & RINA MELLYA SUCI, S. Pd & GURU & \\
\hline 13 & RISNAWATI, S. Pd & GURU & \\
\hline 14 & RIYANTO, S. Pd & GURU & \\
\hline 15 & SANDI RUSTANDI, S. Pd & GURU & \\
\hline 16 & SRIWATI BADILLAH, S. Ag & GURU & \\
\hline 17 & SYABANI SAPTA PRIHARTONO, S. Pd & GURU & \\
\hline 18 & TRIO ANJAR KOSMARA, S. Pd & GURU & \\
\hline 19 & UJANG UKARDI, S.Pd.Si & GURU & \\
\hline 20 & WINDA TRI UTOMO, S. Pd & GURU & \\
\hline 21 & YUSI YUSFITASARI M, S. Pd & GURU & \\
\hline 22 & BANIAH, S.Pd. & GURU & \\
\hline 23 & DEDI IRAMA, S.Sos & GURU & \\
\hline 24 & TITI YULIANTI, S.Pd & GURU & \\
\hline 25 & DADAN RUSMANTO, S.Pd & GURU & \\
\hline 26 & RESTIAWATI, S.Pd & GURU & \\
\hline 27 & ASEP SETIAWAN S.Pd & STAF & \\
\hline 28 & LENI HERLINA & STAF & \\
\hline 29 & RIANI, SE & STAF & \\
\hline 30 & GUGUN WIGUNA, S.AP & STAF & \\
\hline 31 & ELYSA TITANIA & STAF & \\
\hline 32 & SUKARDI & STAF & \\
\hline
\end{tabular}

Pangandaran, Juli 2020

Kepala Sekolah 